\title{
Art in Early Modern Italy: Artemisia Gentileschi and Caravaggio
}

\author{
By: Joslin Holwerda
}

During the early modern period, Italy became the centre of Europe's most notable cultural movements. In the late sixteenth century, a new era of art and culture began to emerge. The Baroque period originated in Italy during a time of intense religious, social, and political turmoil in Europe. ${ }^{1}$ This new era of painting, architecture, and music gave artists and patrons the necessary means to express their abilities and interests in increasingly extravagant ways. Unlike past movements, paintings and sculptures featured dramatized depictions of historic and religious events, created to incite emotions. A majority of the paintings from this time became distinguished parts of Rome, located throughout the city's buildings and churches.

With the Baroque era came new artists who had the passion and necessary skill to thrive as professional painters. Rome, in particular, became home to a diverse array of painters whose works and achievements came to define the Baroque period. Among the many painters from this era were two whose careers and art played pivotal roles in the prosperity and prominence of Rome's Baroque period. Michelangelo Merisi da Caravaggio and Artemisia Gentileschi had illustrious careers as painters in Rome, though their lives and works came to represent broader gender relations in seventeenth-century Italy.

Michelangelo Merisi da Caravaggio was one of Rome's most celebrated, and controversial, artists of the seventeenth century. Though he began his career in poverty, Caravaggio quickly developed a following in Rome's art circles. His success is

\footnotetext{
${ }^{1}$ Cait Caffrey, "Baroque Period," 2016, Salem Press Encyclopedia Research Starters, EBSCOhost.
} 
demonstrated by the considerable amount of commissions he began receiving from notable, wealthy figures throughout Italy. While he continued to thrive as a professional artist, Caravaggio's personal life began to have an effect on his art. His notoriously violent personality, which led to an extensive criminal record, had an influence on the mood of his paintings. Caravaggio often faced backlash for his violent and disgraceful portrayals of biblical scenes. Rather than preventing him from thriving as an artist, however, Caravaggio's controversial paintings and violent personality established him as Italy's greatest painter of the Baroque period.

Caravaggio's career in Italy differed greatly from that of Gentileschi's. During her career of over forty years, Artemisia Gentileschi established herself as one of Italy's leading female painters. Despite her talent, she was not given the same opportunities as her male contemporaries, putting her career at a clear disadvantage. However, her lack of professional art training did not stop her from pursuing a career as an artist. While she lived most of her life in poverty and in debt, Gentileschi was able to make a name for herself internationally. ${ }^{2}$ Numerous high-ranking patrons supported her art, even when most considered it to be drastically different from others in the Baroque era, especially when compared to the works of male artists. Gentileschi's predominant use of female protagonists, depicted mostly as dominant figures, is often attributed to her experiences in life as a woman and as a rape survivor. Regardless of her success, Gentileschi's reputation, recognized by both contemporaries and by scholars today, has turned on gender rather than her accomplishments.

\footnotetext{
${ }^{2}$ Elizabeth Cropper, "New Documents for Artemisia Gentileschi's Life in Florence," The Burlington Magazine 135, no. 1088 (1993): 760.
} 
Although there was a distinct female presence in Roman streets and urban spaces, there was a clear dichotomy between genders in the seventeenth century. Despite being a renowned painter whose accomplishments were internationally celebrated, Gentileschi experienced professional and personal disadvantages during her career that Caravaggio never encountered as a male painter. The professional challenges that Artemisia Gentileschi faced, as a woman in the seventeenth century, reflects the broader gender relations of early modern Italy.

By the early seventeenth century, Rome was a newly transformed metropolitan city with a passion for the arts. ${ }^{3}$ In years prior, the papal city had experienced processes of urban reform, led by Pope Sixtus V. Sixtus' plan was to improve the existing urban fabric of Rome and create a transparent and modern city. ${ }^{4}$ Large new architectural spaces were created across Rome, with wide straight avenues encircling the dense urban core of the city. ${ }^{5}$ Existing palaces, churches, and monasteries were expanded and decorated in ways that conformed them to the city's extravagant new look. ${ }^{6}$ Rome's urban expansion, occurring in the last years of the sixteenth century, coincided with Europe's CounterReformation. This meant new churches were emerging throughout Rome, changing the overall landscape and architecture of the city.

In order to accomplish everything that was set out in Sixtus' urban reform plan, groups of workers, builders, and sculptors were drawn to Italy to begin the immense task

\footnotetext{
${ }^{3}$ Mary D. Garrard, Artemisia Gentileschi: The Image of the Female Hero in Italian Baroque Art (Princeton: Princeton University Press, 1988), 13.

${ }^{4}$ Charles Burroughs, "Opacity and Transparence: Networks and Enclaves in the Rome of Sixtus V," RES: Anthropology and Aesthetics, no. 41 (2002): 57-59.

${ }^{5}$ Garrard, Artemisia Gentileschi, 13.

${ }^{6}$ Elizabeth S. Cohen, “To Pray, To Work, To Hear, To Speak: Women in Roman Streets c. 1600,” Journal of Early Modern History 12 (2008): 296.
} 
of renovating Rome. ${ }^{7}$ Entire communities of artists and builders, mostly from northern Italy, took over Rome as it became the epicentre of cultural change and opportunity. ${ }^{8}$ The architectural transformation of the city was quickly followed by an increase in paintings, on both canvas and in fresco, specifically commissioned for the palaces and churches of Rome. ${ }^{9}$ The artistic endeavours of the early seventeenth century became part of the newly emerging Baroque period. The Baroque style originated in Italy and quickly became popular among painters, sculptures, and architects. ${ }^{10}$ Most of the art commissioned in the later years of Sixtus' urban transformation was characterized by the Baroque style. This style largely focused on ecclesiastical art, with religious themes and religious events depicted in most paintings and sculptures. ${ }^{11}$ Scenes were created, and often commissioned, in order to reiterate the importance of the church and religious values following the Reformation. ${ }^{12}$ A rising demand from private buyers in the elite and middle classes also led to genre paintings, depicting everyday life in landscapes and still-lifes, although biblical stories remained the most desirable. ${ }^{13}$

Rome's urban renewal created a modern environment with a much denser population, offering the city and its people increasing mobility. Roman streets were dangerous urban spaces, but they were also full of opportunity and allowed people the ability to grow social connections. ${ }^{14}$ Most notably, urban streets gave women in Rome the opportunity to increase their mobility in society. Despite males dominating urban places,

\footnotetext{
${ }^{7}$ Stefano Zuffi, Caravaggio: Masters of Art (Munich, New York: Prestel, 2012), 14.

${ }^{8}$ Alfred Moir, Caravaggio (New York: H.N. Abrams, 1982), 15.

${ }^{9}$ Garrard, Artemisia Gentileschi, 13.

${ }^{10}$ Caffrey.

${ }^{11}$ Ibid.

${ }^{12}$ Ibid.

${ }^{13}$ Federico Etro, et al, "The Labor Market in the Art Sector of Baroque Rome," Economic Inquiry 53, no. 1 (2015): 367

${ }^{14}$ Cohen, "To Pray, To Work, To Hear, To Speak," 298.
} 
women regularly made use of them as well. Working-class women spent a great deal of time in urban spaces for various reasons, but for most women it was essential because they could participate in work obligations. ${ }^{15}$ Such work included art, and the changes occurring in Rome gave artists the necessary opportunities to make art a viable career. However, most female artists were not given the same opportunities as men to achieve success. In 1559, Annibale Caro, an Italian writer and poet, called painting "the profession of gentlemen" and expressed the general reluctance of men to acknowledge women's artistic skills. ${ }^{16}$ Along with being labelled as incapable and essentially excluded from the profession, women were also prohibited from guilds, academies, and artistic training. ${ }^{17}$ Despite the disadvantages of their gender, some women in early modern Italy did succeed as artists, although they were often overshadowed by the careers of male artists.

Caravaggio was one such artist to benefit from the urban and cultural transformations in Rome in the seventeenth century. Born Michelangelo Merisi on 29 September 1571, he grew up in Milan in a middle-class family. ${ }^{18}$ His father, Fermo Merisi, and his father's new wife, Lucia Aratori, managed the estate and properties of the Marchese of Caravaggio, a well-known farming community north of Milan. ${ }^{19}$ In 1576 , when Caravaggio was only six years old, one of Europe's deadliest plagues made its way into Italy, causing tens of thousands to die. Fermo Merisi, along with Caravaggio's

\footnotetext{
${ }^{15}$ Ibid, 306-307.

${ }^{16}$ Babette Bohn and James M. Saslow, "From Oxymoron to Virile Paintbrush: Women Artists in Early Modern Europe," in A Companion to Renaissance and Baroque Art (Chichester, West Sussex: WileyBlackwell, 2013), E-book edition, chap. 11.

${ }^{17}$ Ibid.

${ }^{18}$ Zuffi, 10.

${ }^{19}$ Ibid.
} 
grandfather and uncle, were all victims of the plague in late $1577 .{ }^{20}$ Caravaggio remained in Milan, living with his mother and four siblings until November of 1590 when Lucia Merisi died. ${ }^{21}$ The now orphaned Merisi children were left deeply in debt, prompting Caravaggio to sell most of his inherited land in the following years, though he likely spent the money he received unwisely. In 1592, with the intention to move to Rome, Caravaggio quickly divided his inherited property a final time between his two remaining siblings, leaving him with an inheritance of 393 Imperial pounds. ${ }^{22}$ With this being enough to support him for the next few years, Caravaggio left for Rome, arriving around 1592 at the age of twenty-one with the desire to become a painter.

Before this move, while growing up in Milan, Caravaggio spent most of his childhood receiving professional artistic training from his apprenticeship with Milanese painter Simone Peterzano. ${ }^{23}$ His apprenticeship with Peterzano began at the age of twelve, where he worked for four years in Peterzano's home while being taught how to paint. During his time in Milan, Peterzano was involved in the decoration of many churches in the Renaissance styles of the late sixteenth century. Peterzano used his own paintings, as well as the works of Titian and Leonardo da Vinci, to teach Caravaggio the fundamentals and basic principles of painting in the Milanese style. ${ }^{24}$ Despite being a difficult student, and oftentimes refusing to learn techniques like painting frescoes, Caravaggio was a well-educated and gifted painter.

In 1592, after the death of his mother, Caravaggio moved to Rome, where urban renewal had made the city increasingly appealing to artists. By the late sixteenth century,

\footnotetext{
${ }^{20}$ Howard Hibbard, Caravaggio (New York: Harper \& Row, 1982), 12.

${ }^{21}$ Zuffi, 14.

${ }^{22}$ Hibbard, 5.

${ }^{23}$ Zuffi, 13 .

${ }^{24}$ Hibbard, 4.
} 
the city had established itself as the epicentre for art, but Caravaggio did not immediately find success. During his early years in Rome, Caravaggio was extremely poor and worked for minor artists, doing demeaning work in order to make money ${ }^{25} \mathrm{He}$ also began showing his paintings in public outdoor exhibits, which was considered the lowest category of artist merchandising. ${ }^{26}$ His early works were painted with the sole intention to sell large quantities, as he did not yet have commissions. Roman streets and those he encountered in his everyday life often influenced these paintings. His first patron, the influential Cardinal Francesco Maria del Monte, took note of Caravaggio's paintings, purchased several, and encouraged him to continue a career in art. The Cardinal also offered him accommodations, giving Caravaggio access to the Roman aristocracy and other wealthy patrons ${ }^{27}$ From this point on, Caravaggio became Rome's newest and most impressive painter.

Caravaggio's first public commission in 1599 was for two paintings, including an altarpiece, for San Luigi dei Francesi, the national church of France in Rome. ${ }^{28}$ His specific instructions were to create a piece related to the theme of St. Matthew. Caravaggio's first depiction of St. Matthew, however, was rejected by the church for its crude realism, but was accepted after his second attempt, receiving four hundred scudi in return. ${ }^{29}$ The Calling of St. Matthew was Caravaggio's final painting in the style he had developed while in Rome, now devoting his career exclusively to religious themes and subjects. ${ }^{30}$

\footnotetext{
${ }^{25}$ Ibid, 6-8.

${ }^{26}$ Ibid, 16-17.

${ }^{27}$ Zuffi, 16.

${ }^{28}$ Ibid.

${ }^{29}$ Hibbard, 91-92.

${ }^{30}$ Zuffi, 16-20.
} 
Caravaggio received almost constant commissions in the early seventeenth century, becoming well-known both in Roman art circles and across Europe. He was commissioned by several patrons to decorate chapels and churches throughout Rome. Despite becoming a renowned painter, Caravaggio was also one of Italy's most controversial. Around 1605, Caravaggio received a commission from the Archconfraternity of the Papal Grooms to complete a painting intended for St. Peter's Basilica. The painting was intended to show Mary, with Jesus standing on the head of a serpent, a symbol for sin, accompanied by St. Anne, the mother of Mary. Instead, Caravaggio chose to paint Mary with her foot also on the serpent's head, to show that she had overcome Original Sin with the help of her son. ${ }^{31}$ The Archconfraternity took issue with Caravaggio's disregard for the original message, and his realistic depiction of the holy figures. The nakedness of Jesus, the elderly portrayal of St. Anne, and the fact that Caravaggio had a prostitute model Mary, all played a part in the Archconfraternity's rejection of the Madonna dei Palafrenieri (Figure 2.1).

Caravaggio's controversial paintings were a continuous theme in his career as an artist. Patrons often refused to display his work, but his commissions were never seriously affected, and he continued to receive commissions from some of Italy's most notable figures. Despite constant backlash from patrons, Caravaggio's controversial style and unwillingness to adapt for commissioned works did not have an effect on his career. The professional challenges faced by Caravaggio were largely self-produced and did not derive from social restrictions.

\footnotetext{
${ }^{31}$ Ibid.
} 
The style and themes depicted in Caravaggio's paintings changed throughout his years in Italy. In the early years of his career, those he encountered on the streets of Rome influenced much of Caravaggio's art. The Fortune Teller, The Cardsharps, and later, Death of the Virgin, all demonstrate the impact that ordinary life in Rome had on Caravaggio's art style. In The Fortune Teller a gypsy woman is telling the fortune of a well-dressed young man (Figure 2.2).

While reading his palm, the woman slips a ring off of his finger without him noticing. This painting, of an event from everyday life, is a reminder not to be fooled by attractive deceptions. ${ }^{32}$ Caravaggio painted The Fortune Teller in 1594 soon after arriving in Rome and experiencing the city's streets for the first time. ${ }^{33}$ The Cardsharps, also painted around 1594, shows two young boys playing cards, one being a cardsharp (Figure 2.3). The cardsharp attempts to trick the unsuspecting boy with the help of an older man, most likely his accomplice. ${ }^{34}$ The tear in the older man's gloves and the feather in the cardsharp's hat offer realistic impressions. Both The Fortune Teller and The Cardsharps express realistic scenes of Roman street life. They successfully demonstrate Caravaggio's interest in the drama of everyday life on the streets of Rome, depicted in several of his paintings.

In the $1600 \mathrm{~s}$, Caravaggio established himself as a religious artist, focusing on biblical scenes and religious themes. However, his carefree handling of religious subjects shocked Rome and his patrons. For example, The Death of the Virgin was a commission for the church of Santa Maria della Scalla (Figure 2.4). ${ }^{35}$ The painting shows the

\footnotetext{
${ }^{32} \mathrm{Ibid}, 36$.

${ }^{33}$ Ibid.

${ }^{34}$ Ibid, 38.

${ }^{35}$ Ibid, 104.
} 
Apostles and Mary Magdalene grieving together over the deathbed of Mary. Caravaggio had the ability to bring reality to his religious paintings, reflected in the figures and setting of this painting. The overly-realistic portrayal of Mary was one of the reasons why The Death of the Virgin was controversial. Her chalk-white, bloated figure and her bare feet hanging off the bed upset the monks who had commissioned it. ${ }^{36}$ In addition, Caravaggio again used a prostitute to model for Mary, increasing the offensiveness of the painting. And yet, despite his controversial art style and paintings, Caravaggio's career continued to be a success.

Since his time in Milan, Caravaggio was known to have a violent personality with frequent confrontations with authorities. On 28 May 1606, Caravaggio was involved in a violent altercation between himself and a group of men, over a disagreement about a wager for a tennis match. ${ }^{37}$ During the fight, Caravaggio killed Ranuccio Tomassoni and subsequently fled Rome in order to escape execution. For the next several years, Caravaggio lived in Naples where he continued his successful career as a commissioned painter. He painted for the Knights Hospitaler of St. John in Malta in 1608, receiving an honorary knighthood. ${ }^{38}$ After a brief imprisonment in Malta for attacking a knight, Caravaggio travelled to Syracuse, Sicily, and Naples, continuing to receive commissions while still wanted for his crimes in Rome. In early 1610, Ferdinando Gonzaga of Mantua became cardinal and began soliciting a pardon for Caravaggio. ${ }^{39}$ However on 18 July 1610 on the shore of the Tyrrhenian Sea, while travelling back to Rome in hopes of

\footnotetext{
${ }^{36}$ Ibid.

${ }^{37}$ Hibbard, 206.

${ }^{38}$ Ibid, 228.

${ }^{39}$ Ibid, 254.
} 
reconciliation, Caravaggio died. ${ }^{40}$ Despite his violent and controversial life, Caravaggio's successful career and art represented the Baroque period and thoroughly transformed Italian painting. The lack of social restrictions and professional challenges that Caravaggio faced, despite being a controversial figure, is reflective of the gender hierarchy in Italy at this time.

In contrast, Artemisia Gentileschi—despite her significant accomplishments and illustrious career-encountered great adversity as a female artist in seventeenth-century Italy. The personal and professional disadvantages she faced, especially when compared to male artists such as Caravaggio, had an immense impact on the success of her career. Artemisia Gentileschi was born on 8 July 1593 in Rome to Orazio Gentileschi and his wife Prudentia Montone. ${ }^{41}$ As the only daughter of Orazio, a moderately successful painter, growing up in Rome surrounded by artists, Gentileschi quickly developed an interest for the arts and painting. However, women in early modern Italy were not allowed to participate in normal paths to artistic careers. Along with being excluded from apprenticeships, women were not allowed to train with more than one established master, travel, or have membership in guilds. ${ }^{42}$ Instead, like many aspiring women artists at this time, Gentileschi received her artistic training through her father. ${ }^{43}$ By nineteen, with her extraordinary talent and extensive informal training, Gentileschi began assisting in her father's workshop, as well as helping him on major projects, including decorating several of the new palazzi being built in early seventeenth-century Rome. ${ }^{44}$ She also began

\footnotetext{
${ }^{40}$ Ibid.

${ }^{41}$ Garrard, Artemisia Gentileschi, 13.

${ }^{42}$ Ibid.

${ }^{43}$ Bohn, chap. 11.

${ }^{44}$ Griselda Pollock, Differencing the Canon: Feminist Desire and the Writing of Art's Histories (New York: Routledge, 1999), 103.
} 
working on her own paintings, with her first most likely being Susanna and the Elders in 1610 , when she was only seventeen years old. ${ }^{45}$

Gentileschi's exclusion from professional training, while putting her at a disadvantage, did not prevent her from continuing to learn. Being a professional painter in Rome, Orazio had access to many talented colleagues who were willing to teach Gentileschi the fundamentals of painting. In 1611, Orazio arranged for his daughter to study perspective with his friend and colleague, Agostino Tassi. ${ }^{46}$ In May of 1611 , while working on a portrait at her home, Tassi began flirting with Gentileschi and when she denied his advances, he raped her. ${ }^{47}$ As she fought back against the assault, Tassi promised marriage to mollify her and she accepted. ${ }^{48}$ While the loss of one's virginity before marriage did not completely destroy a girl's life in seventeenth-century Rome, premarital sex was still religiously and socially prohibited. ${ }^{49}$ Gentileschi's marriage prospects would have significantly declined after forcibly losing her virginity, thus a promise of marriage, even by her rapist, would have seemed like her only option.

Tassi and Gentileschi continued a sexual relationship until March 1612, when Orazio brought a suit against Tassi for the rape of his daughter. ${ }^{50}$ The trial lasted seven months, with Tassi and several other alleged accomplices testifying against the charges. During the trial, Tassi proposed a series of counter-allegations against Gentileschi's chastity in an attempt to make her seem immoral, claiming that "[Orazio] stated to me

\footnotetext{
${ }^{45}$ Garrard, Artemisia Gentileschi, 13.

${ }^{46}$ Pollock, 105.

${ }^{47}$ Elizabeth S. Cohen, "The Trials of Artemisia Gentileschi: A Rape as History," The Sixteenth Century Journal 31, no. 1 (2000): 49.

48 Ibid.

${ }^{49}$ R. Ward Bissell, Artemisia Gentileschi and the Authority of Art: Critical Reading and Catalogue Raisonné (University Park, PA.: Pennsylvania State University Press, 1999), 17.

${ }^{50}$ Mary D. Garrard, "Testimony of the Rape Trial of 1612," in Artemisia Gentileschi: The Image of the

Female Hero in Italian Baroque Art (Princeton: Princeton University Press, 1988), 403.
} 
that by saying that his daughter was leading a bad life he meant that she was a whore, and that he didn't know how to remedy this." ${ }^{51}$ Along with being accused by Tassi, Gentileschi was voluntarily tortured with the sibille on several occasions, in order to prove that she was being truthful during her testimony. ${ }^{52}$ Ultimately, it is likely that Tassi was convicted but not sentenced and was subsequently released after spending only nine months in prison. ${ }^{53}$ Gentileschi's rape and trial were pivotal moments in her life. While her rape did not damage her reputation, it was a turning point in her career as an artist. Several of Gentileschi's paintings offer portrayals of vulnerable women heroically resisting attacks, images of strong and assertive women, and of resistance to the patriarchy.$^{54}$ Instead of repressing the rape and trial, Gentileschi used these experiences as inspiration for her paintings.

As a professional female painter in seventeenth-century Italy, Gentileschi encountered both resistance and acceptance. After the rape trial concluded in 1614, she moved to Florence with her new husband to pursue a career separate from that of her father. ${ }^{55}$ By 1615 , Gentileschi was described by contemporaries as a well-known artist in Florence ${ }^{56}$ Her easy acceptance into Florentine art circles can be explained by her position as protégée of Michelangelo Buonarroti the Younger, a prominent Florentine and long-time patron during her career. ${ }^{57}$ Gentileschi's first documented commission was for

\footnotetext{
${ }^{51}$ Garrard, "Testimony of the Rape Trial of 1612," 447.

52 Ibid, 404.

${ }^{53}$ Ibid, 406.

${ }^{54}$ Cohen, "The Trials of Artemisia Gentileschi," 47.

${ }^{55}$ Keith Christiansen et al, Orazio and Artemisia Gentileschi (New York: Metropolitan Museum of Art; New Haven: Yale University Press, 2001), 313.

${ }^{56}$ Garrard, Artemisia Gentileschi, 34.

${ }^{57}$ Mieke Bal, The Artemisia Files: Artemisia Gentileschi for Feminists and Other Thinking People (Chicago: University of Chicago Press, 2005), 119.
} 
Buonarroti's home in 1615 , for which she received a substantial amount. ${ }^{58}$ Throughout her career, Gentileschi received numerous commissions from prominent people across Europe. This included an extended professional relationship with the Grand Duke and Duchess of Florence, who supported her career for many years until the Duke's death in 1621. ${ }^{59} \mathrm{By}$ the time she returned to Rome in the $1620 \mathrm{~s}$, following the Duke's death, numerous notable artists and members of Rome's society had pronounced her a marvel.

For many years after 1621, Gentileschi periodically travelled throughout Italy, and briefly to England, where she gained immense international recognition for her paintings. Her lack of large fresco commissions did not impact her fame. ${ }^{60}$ In personal letters from 1635, she stated that she had previously received commissions from several European monarchs, including the kings of France and Spain, and, most notably, King Charles I of England ${ }^{61}$ In 1638, Gentileschi resided in England at the court of Charles I, where she worked alongside her father, for a final time, to complete his commission of decorating the ceiling of the Queen's house at Greenwich ${ }^{62}$ For nearly a decade after her return to Italy in 1642, Gentileschi, despite facing professional limitations throughout her life, was a remarkably successful painter, whose determination and skill attracted prestigious patrons from across Europe.

And yet, despite her success, Gentileschi faced financial and professional struggles throughout her life. Her years in Florence are the best documented of her career, showing that a significant concern for her was money. Gentileschi was always in need of money and had a constant problem with debt, primarily as a result of not being able to

\footnotetext{
${ }^{58}$ Garrard, Artemisia Gentileschi, 34-35.

${ }^{59}$ Keith Christiansen et al, Orazio and Artemisia Gentileschi, 228.

${ }^{60}$ Ibid, 271.

${ }^{61}$ Garrard, Artemisia Gentileschi, 90.

${ }^{62}$ Ibid, 112.
} 
pay the high costs for materials, including models for her paintings. ${ }^{63}$ These debts also led to many years of legal troubles, though the Grand Duke attempted to help her find ways to reduce her debt. ${ }^{64}$

On several occasions, Gentileschi sent letters to patrons asking for an advance on their commissions. In 1649, she asked for a deposit from Don Antonio Ruffo, her primary patron in the later years of her career, while also pleading for him not to reduce the price of his commission. "I cannot give it to you for less than I asked," she wrote, "as I have already overextended myself to give the lowest price." ${ }^{65}$ In her letter, Gentileschi attempted to prove to Ruffo that her painting was worth the price for which that she had asked. This letter, which was sent at the end of her career, demonstrates how Gentileschi still had to justify her talent to patrons, despite being a well-known professional female artist in seventeenth-century Italy.

While living in Rome, Gentileschi could not become a member of the Roman Accademia di S. Luca, which prohibited women from attending any of the meetings or private instructional programs it held. ${ }^{66}$ After moving to Florence and emerging as a successful artist in the community, however, Gentileschi used her personal connections to gain entry into the Florentine Accademia del Disegno. In 1616, Gentileschi became the first female member of the Florentine Academy, which helped artists develop and sustain their notability. ${ }^{67}$ Despite facing professional challenges in her career, Gentileschi's

\footnotetext{
${ }^{63}$ Ibid, 135.

${ }^{64}$ Cropper, 760.

${ }^{65}$ Artemisia Gentileschi to Don Antonio Ruffo, 1649, in Early Modern Europe, 1450-1789, ed. Merry E. Wiesner-Hanks (Milwaukee: Cambridge University Press, 2013).

${ }^{66}$ Garrard, Artemisia Gentileschi, 34.

${ }^{67}$ Bal, 119.
} 
acceptance into the Accademia del Disegno was a massive personal and professional accomplishment for both Gentileschi and female artists in early modern Italy.

The struggles that Gentileschi encountered in her life as a woman in seventeenthcentury Italy had a profound impact on her interpretations of bible stories and how she chose to portray women in her paintings. Throughout her works, there are noticeable themes that reflect the feelings she held towards the patriarchy and violence against women. Being a rape victim herself, Gentelischi's portrayal of Susanna in Susanna and the Elders differs greatly from other, primarily male artists, who worked with this subject (Figure 2.5). The painting, based off a biblical story, shows Susanna and two elderly men demanding that she submit to them sexually, threatening to accuse her of adultery if she does not comply. Susanna refuses, even though the punishment for adultery is death, and is pictured visibly denying their advances. ${ }^{68}$ Though the painting was dated 1610 , prior to Gentileschi's rape and trial, her depiction of sexual violence and violation is a clear reflection of how she felt about society's problems with sexual abuse and sexual vulnerability.

Gentileschi's painting from 1620, Judith and Her Maidservant, demonstrates her portrayal of female protagonists as strong heroines (Figure 2.6). In the painting, Judith denotes an imposing forcefulness with her sword, showing that she is attentive and ready to fight if needed. ${ }^{69}$ Like Judith and Her Maidservant, Gentileschi's Jael and Sisera also depicts the woman in a strong, assertive position (Figure 2.7). Unlike other portrayals of Jael, Gentileschi's interpretation focuses on Jael acting in quiet deliberation rather than

\footnotetext{
${ }^{68}$ Bohn chap. 11.

${ }^{69}$ Bal, 88.
} 
with passion. ${ }^{70}$ Her positive portrayal of Jael differs greatly from that of male painters, especially as it removes any sexual appeal and unnecessary evil connotations. ${ }^{71}$ The abundance of female protagonists represented in Gentileschi's paintings is unlike any others at this time. Her heroic characterizations of women and their resistance to submissiveness demonstrate how Gentileschi's experiences in life, including her resistance to dominant gender norms, influenced her career as an artist. The professional challenges and limitations she experienced during her career represent the lives of women in early modern Italy. Despite her immense talent and success, Gentileschi was not considered equal when compared to her male contemporaries. As a woman in the public sphere, Artemisia Gentileschi encountered disadvantages solely because of her gender.

One of the most prevalent biblical figures in paintings during the Baroque period was the Israelite widow, Judith. During their careers, both Caravaggio and Gentileschi featured the same biblical story of Judith, in their paintings. Their interpretations of her story differ greatly, despite the influence of Caravaggio's version on Gentileschi. Gentileschi, who had grown up in Rome at the height of Caravaggio's career, was surrounded by his works. Additionally, Gentileschi's father was a colleague and close follower of Caravaggio's, which meant she was taught primarily in Caravaggio's style of painting. ${ }^{72}$ By the time Gentileschi began her apprenticeship with her father, Caravaggio's painting, Judith Beheading Holofernes, was well-known in Rome since its creation in 1599 (Figure 2.8).

\footnotetext{
${ }^{70}$ Ibid, 109.

${ }^{71}$ Garrard, Artemisia Gentileschi, 340.

${ }^{72}$ Ibid, 14.
} 
However, when compared to Gentileschi's Judith Slaying Holofernes dated 1614, it is apparent that gender had a significant impact on their interpretations of the story (Figure 2.9). In Caravaggio's depiction of the beheading of the Assyrian General Holofernes, Judith is seen standing to the side, focused intently on the victim. Her face shows either a mixture of cold-bloodedness and revulsion or awkward determination, with her servant calmly watching at her side. ${ }^{73}$ While the lighting in the painting makes it so Judith and her servant are the focus, they are overshadowed by Holofernes who is taking up most of the scene. The women are not given equal space in the painting, which is a recurring issue in Caravaggio's work. ${ }^{74}$ Caravaggio's entire focus is on the action of the beheading and of death. While Judith is the one beheading Holofernes, she is ultimately portrayed as submissive in this depiction. The distance between her and Holofernes and the lack of emotion on Judith's face make her seem extremely passive.

Gentileschi's depiction of the bible story, through her painting Judith Slaying Holofernes, differs greatly in comparison to Caravaggio's. The most obvious and noteworthy difference between the two interpretations is the positioning of Judith and her servant. Rather than being relegated to the side as in Caravaggio's painting, Judith and her servant are directly on top of Holofernes, holding him down while beheading him. Even though he is struggling, seen in his attempt to push the servant off him, the women are able to successfully overpower him. Gentileschi's interpretation suggests that she expresses her hostile feelings towards men in power. ${ }^{75}$ Judith was painted in 1614 , shortly after Gentileschi's rape and the subsequent trial. ${ }^{76}$ This would account for the

\footnotetext{
${ }^{73}$ Hibbard, 85.

${ }^{74}$ Ibid, 85 .

${ }^{75}$ Pollock, 105.

${ }^{76}$ Garrard, Artemisia Gentileschi, 32.
} 
violence of the piece, as if she employed the beheading of Holofernes as a means to convey anger towards Tassi. Gentileschi emphasises Judith's power in her interpretation, focusing on the strength and determination of the two women. The decision to portray Judith in this way is a result of Gentileschi's personal experiences as a woman in Italy, and specifically as a victim of rape. Her encounter with Tassi, in which she was overpowered and forced to endure sexual assault, influenced the way in which she chose to depict the relationship between Judith and Holofernes. Unlike Caravaggio's portrayal of Judith, in which she is persistent but reserved, Gentileschi's portrayal of strong female protagonists is an explicit refusal to comply with seventeenth-century gender norms.

Throughout their careers, Caravaggio and Gentileschi had complex reputations, shaped by both personal challenges and social expectations of gender. Prejudices against women in the seventeenth century posed considerable obstacles for female artists. Flawed preconceptions about the role of women in society hindered those who tried to achieve some measure of artistic success in early modern Italy. The disadvantages in professional training and opportunity, coupled with expectations of moral and social behaviour of women, defined the success and reputations of female artists such as Gentileschi. While Caravaggio was described as the Baroque era's greatest artist despite his violent past, Gentileschi was often characterized by her sexuality.

There are explicit differences between the contemporary reputations of Caravaggio and Gentileschi. Caravaggio's carefree handling of religion in his paintings shocked his patrons, establishing himself as a controversial artist. Despite having critics and rivals across Italy, his career never suffered. Caravaggio received numerous public commissions during his career, but his controversial style and the subsequent rejections 
did not have any great impact. However, his personal struggles overshadowed his professional scandals. Caravaggio's noted violent behaviour, specifically his murderous actions in 1606 , damaged his reputation briefly after his death. ${ }^{77}$ Although his reputation often centered on his controversial behaviour and art, Caravaggio never experienced restrictions as a professional male artist because of his gender.

Despite being referred to as the greatest female artist of the Baroque age, Gentileschi has never been on equal standing with her contemporary male artists. As she became more popular in Italy, she also experienced greater criticism. Some of her contemporary critics believed it was inappropriate for female artists to be working in public spaces, as they were solely for men to inhabit. ${ }^{78}$ Gentileschi was aware of her disadvantages as a female artist in a masculine field. ${ }^{79}$ In a letter from 1649 to her patron Ruffo about not being paid for a commission she had completed, she said, "If I were a man, I cannot imagine it would have turned out this way." ${ }^{80}$ The professional disadvantages Gentileschi encountered, and the fact that she was regarded as inferior because of her gender, did not go unnoticed.

Though her art was never as controversial as Caravaggio's, the themes depicted in her paintings also emphasized her difference from contemporaries. Gentileschi shifted the focus away from nude models and the sexualisation of women and gave women agency. However, many of her paintings have been lost over the years. This is largely due to the prejudices of contemporaries and the fact that a significant amount of female artwork has

\footnotetext{
77 Zuffi, 29.

${ }^{78}$ Bohn, chap. 11.

${ }^{79}$ Bissell, 116.

${ }^{80}$ Artemisia Gentileschi to Don Antonio Ruffo, 1649, in Artemisia Gentileschi: The Image of the Female Hero in Italian Baroque Art (Princeton: Princeton University Press, 1988), 398.
} 
been wrongly credited to male painters. ${ }^{81}$ This has had a significant impact on the study and commemoration of female artists from the early modern period. However, as a considerable portion of her accomplishments have been preserved since her death, Gentileschi has become well-known and celebrated for choosing to resist male violence and gender norms throughout her career and life in seventeenth-century Italy.

Art is undoubtedly representative of broader gender relations in early modern Italy. The professional restrictions and limitations that were experienced by female artists in the seventeenth century are illustrative of the overall perception of women in the public sphere. The inability for women to receive professional art training and the doubt patrons had about the capabilities of female painters exemplifies the dichotomy between genders in the early modern period. While both Gentileschi and Caravaggio were from similar middle-class families, Caravaggio's ability to become a professional artist was significantly easier than it was for Gentileschi. At a time when there were very few successful female artists in Rome, Gentileschi was able to build a respectable and prosperous career despite the disadvantages facing women in the seventeenth century. Gentileschi's career provided a critical turning point for women in early modern Italy, illustrating how talented woman working in an almost exclusively male profession could overcome considerable obstacles to achieve prominence.

\footnotetext{
${ }^{81}$ Bohn, chap. 11.
} 
Appendix 2

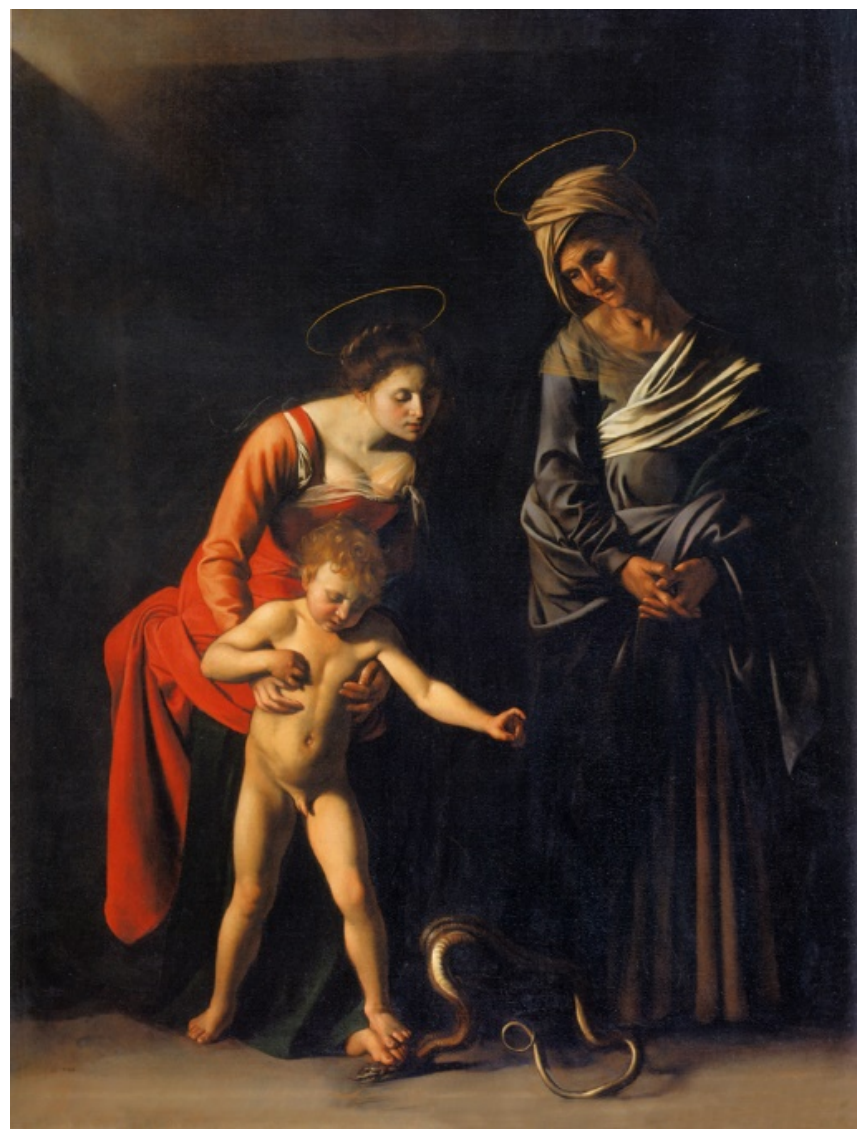

Figure 2.1. Michelangelo Merisi da Caravaggio, Madonna dei Palafrenieri, 1605-1606. Oil on Canvas, 115 x 83". Galleria Borghese, Rome. CWikimedia Commons/Web Gallery of Art.

Figure 2.2. Michelangelo Merisi da Caravaggio, The Fortune Teller, 1595. Oil on Canvas, 115 x $150 \mathrm{~cm}$. Musei Capitolini, Italy. CFlickr/Rodney (CC BYSA 2.0)

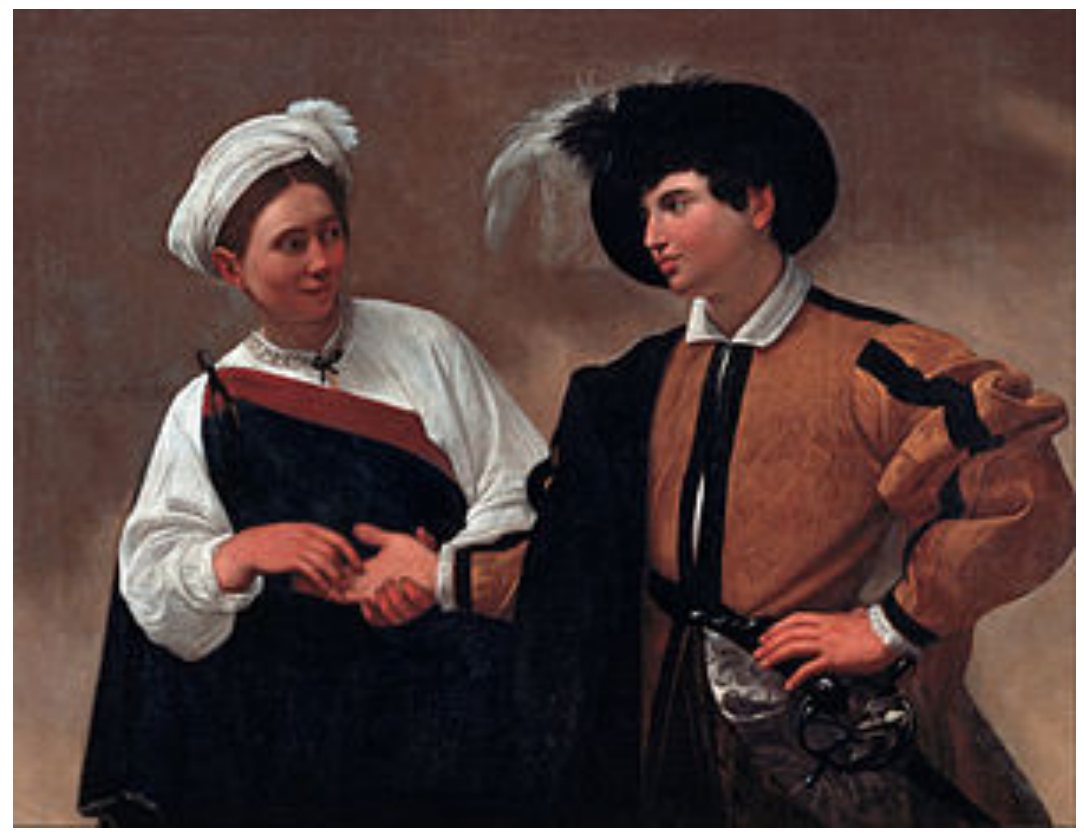


Figure 2.3.

Michelangelo Merisi da Caravaggio, The Cardsharps, 1594. Oil on Canvas, 37 x 52".

Kimbell Art Museum, Texas. CWikimedia Commons/Google Art Project.

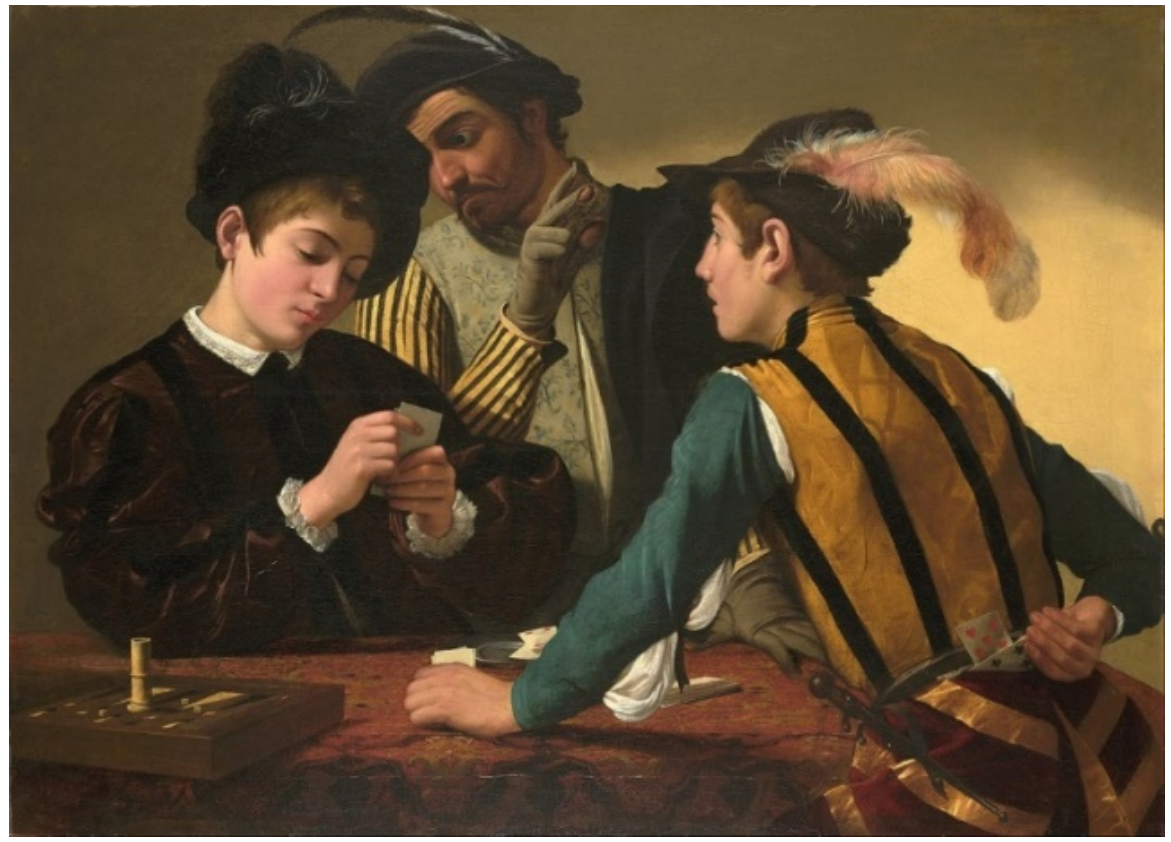

Figure 2.4. Michelangelo Merisi da Caravaggio, Death of the Virgin, c. 1606. Oil on Canvas, $3.69 \times 2.45 \mathrm{~m}$. The Louvre, Paris. (C)Wikimedia Commons/The Yorck Project/Directmedia 


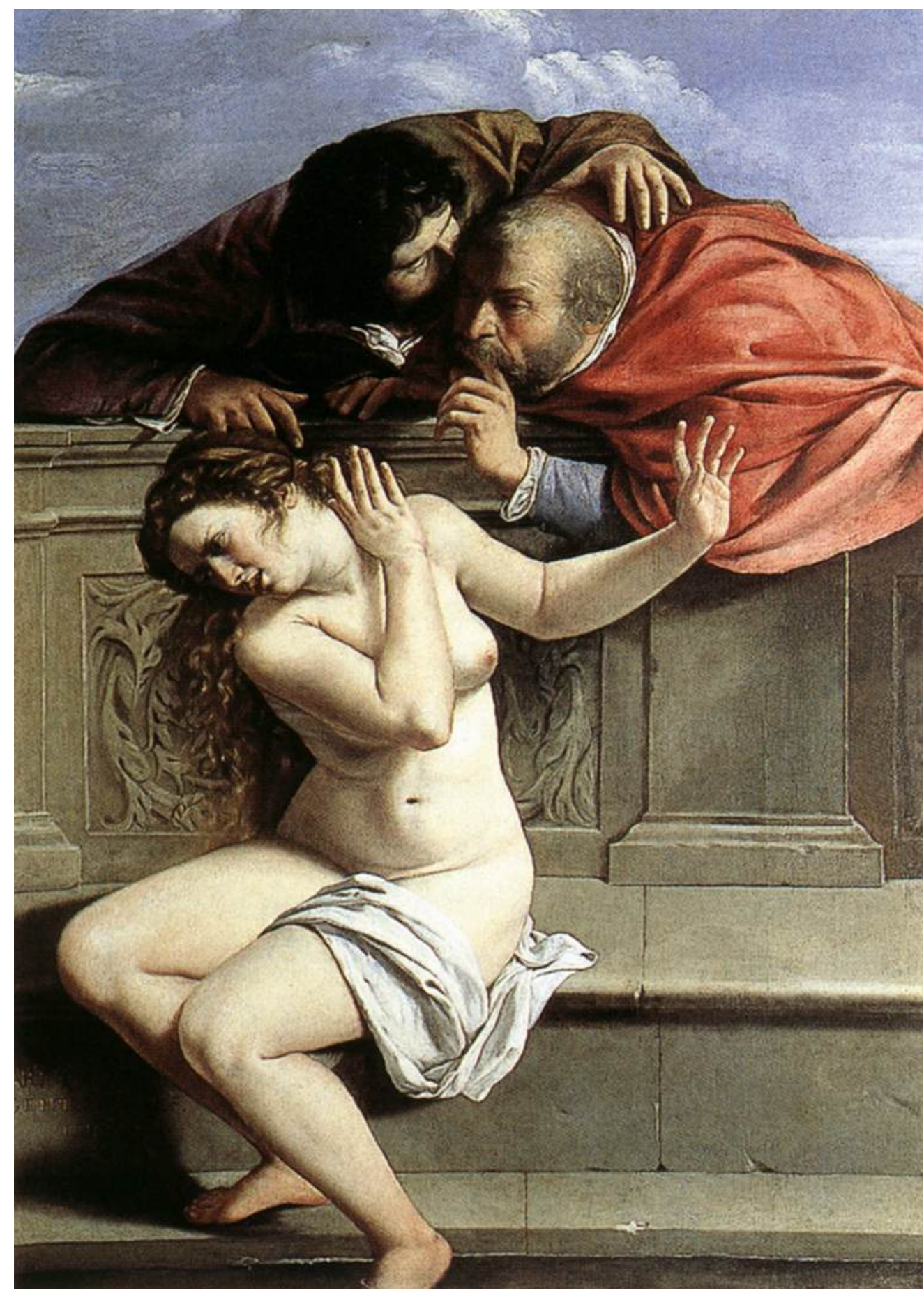

Figure 2.5. Artemisia Gentileschi, Susanna and the Elders, 1610. Oil on Canvas, 1.7 x $1.21 \mathrm{~m}$. Pommersfelden, Germany. CWikimedia Commons/Web Gallery of Art. 




Figure 2.6. Artemisia Gentileschi, Judith and her Maidservant,

1612-1613. Oil on Canvas, $1.14 \mathrm{~m}$ x $94 \mathrm{~cm}$. Palazzo Pitti, Florence. CFlickr/Jennifer Mei.

Figure 2.7. Artemisia Gentileschi, Jael and Sisera, 1620. Oil on Canvas, $86 \times 125$ $\mathrm{cm}$. Museum of Fine Arts, Budapest. CWikimedia Commons/Web Gallery of Art.

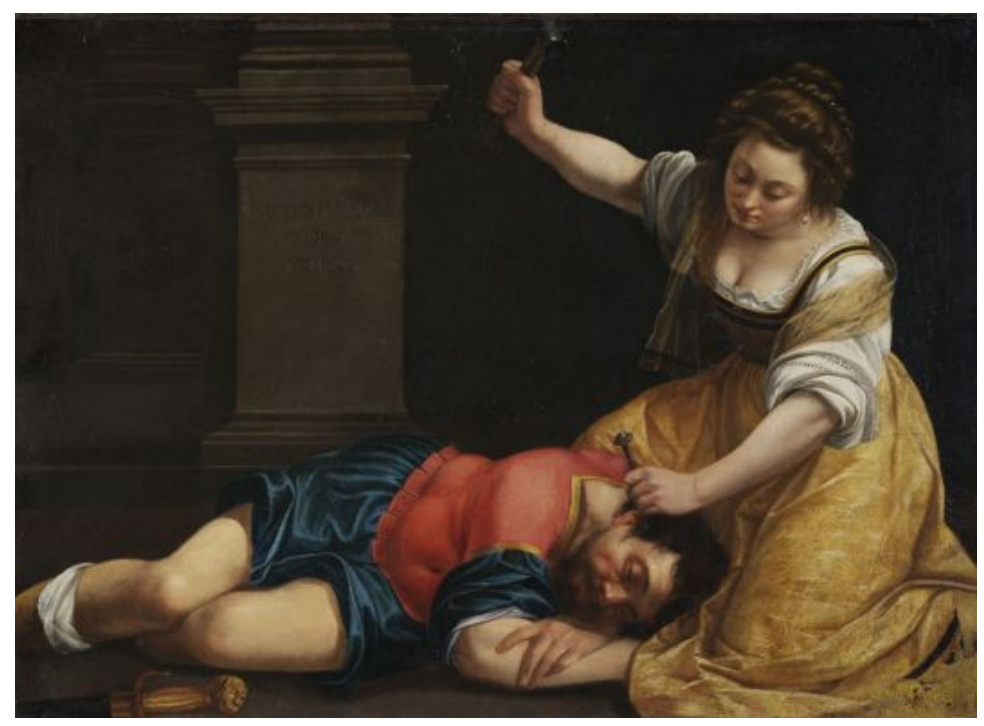


Figure 2.8. Michelangelo Merisi da Caravaggio, Judith Beheading Holofernes, 1599. Oil on Canvas, 145 x $195 \mathrm{~cm}$. Galleria Nazionale d'Arte Antica, Italy. CWikimedia

Commons/All Art Painting
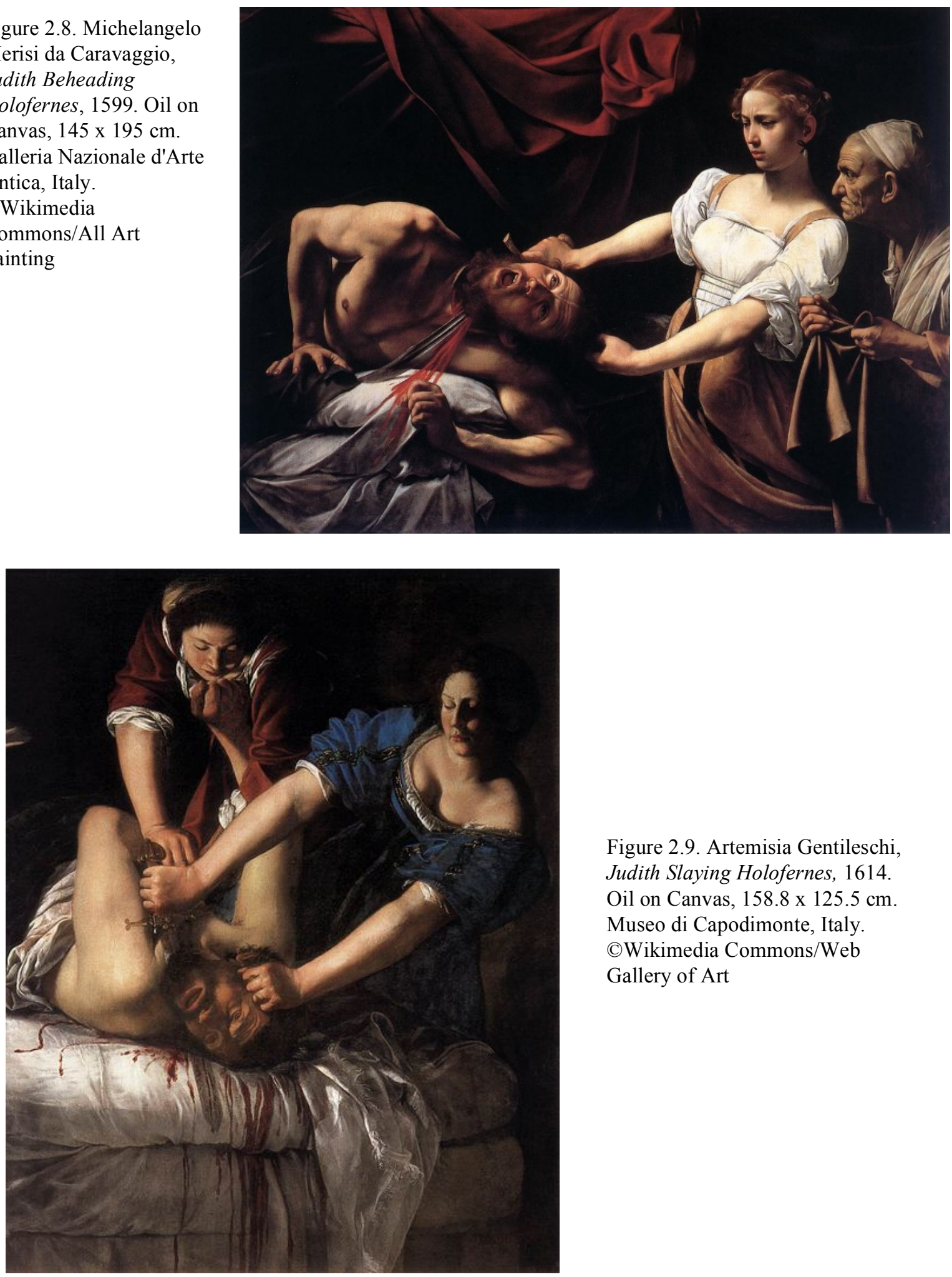

Figure 2.9. Artemisia Gentileschi, Judith Slaying Holofernes, 1614. Oil on Canvas, $158.8 \times 125.5 \mathrm{~cm}$. Museo di Capodimonte, Italy. CWikimedia Commons/Web Gallery of Art 


\section{Bibliography}

Bal, Mieke. The Artemisia Files: Artemisia Gentileschi for Feminists and Other Thinking People. Chicago: University of Chicago Press, 2005.

Bissell, R. Ward. "Artemisia Gentileschi- A New Documented Chronology." The Art Bulletin 50, no. 2 (1968): 153-168.

Bissell, R. Ward. Artemisia Gentileschi and the Authority of Art: Critical Reading and Catalogue Raisonné. University Park, PA: Pennsylvania State University Press, 1999.

Bohn, Babette, and James M. Saslow. "From Oxymoron to Virile Paintbrush: Women Artists in Early Modern Europe." In A Companion to Renaissance and Baroque Art. Chichester, West Sussex: Wiley-Blackwell, 2013. 229-249.

Burroughs, Charles. "Opacity and Transparence: Networks and Enclaves in the Rome of Sixtus V." RES: Anthropology and Aesthetics, no. 41 (2002): 56-71.

Caffrey, Cait. "Baroque Period." 2016. Salem Press Encyclopedia Research Starters, EBSCOhost.

Caravaggio, Michelangelo Merisi da. Death of the Virgin, c. 1606. Oil on Canvas, $3.69 \mathrm{x}$ 2.45 m. The Louvre, Paris. CWikimedia Commons/The Yorck Project/Directmedia

Caravaggio, Michelangelo Merisi da. Judith Beheading Holofernes, 1599. Oil on Canvas, 145 x $195 \mathrm{~cm}$. Galleria Nazionale d'Arte Antica, Italy. CWikimedia Commons/All Art Painting

Caravaggio, Michelangelo Merisi da. Madonna dei Palafrenieri, 1605-1606. Oil on Canvas, 115 x 83.” Galleria Borghese, Rome. CWikimedia Commons/Web Gallery of Art.

Caravaggio, Michelangelo Merisi da. The Cardsharps, 1594. Oil on Canvas, 37 x 52" . Kimbell Art Museum, Texas. CWikimedia Commons/Google Art Project.

Caravaggio, Michelangelo Merisi da. The Fortune Teller, 1595. Oil on Canvas, 115 x 150 cm. Musei Capitolini, Italy. CFlickr/Rodney (CC BY-SA 2.0)

Christiansen, Keith, Judith Walker Mann, Orazio Gentileschi, and Artemisia Gentileschi. Orazio and Artemisia Gentileschi. New York: Metropolitan Museum of Art; New Haven: Yale University Press, 2001.

Cohen, Elizabeth S. "The Trials of Artemisia Gentileschi: A Rape as History." The Sixteenth Century Journal 31, no. 1 (2000): 47-75.

Cohen, Elizabeth S. "To Pray, To Work, To Hear, To Speak: Women in Roman Streets c. 1600." Journal of Early Modern History 12 (2008): 289-311.

Cropper, Elizabeth. "New Documents for Artemisia Gentileschi's Life in Florence." The Burlington Magazine 135, no. 1088 (1993): 760-761. 
Etro, Federico, Silvia Marchesi, and Laura Pagani. "The Labor Market in the Art Sector of Baroque Rome.” Economic Inquiry 53, no. 1 (2015): 365-387. Academic Search Complete, EBSCOhost.

Garrard, Mary D. Artemisia Gentileschi: The Image of the Female Hero in Italian Baroque Art. Princeton: Princeton University Press, 1988.

Garrard, Mary D. "Testimony of the Rape Trial of 1612." In Artemisia Gentileschi: The Image of the Female Hero in Italian Baroque Art. Princeton: Princeton University Press, 1988. 403-488.

Gentileschi, Artemisia. Jael and Sisera, 1620. Oil on Canvas, 86 x $125 \mathrm{~cm}$. Budapest, Museum of Fine Arts. CWikimedia Commons/Web Gallery of Art.

Gentileschi, Artemisia. Judith and her Maidservant, 1613. Oil on Canvas, 93.5 x $114 \mathrm{~cm}$. Italy, Palazzo Pitti. CFlickr/Jennifer Mei.

Gentileschi, Artemisia. Judith Slaying Holofernes, 1614. Oil on Canvas, 158.8 x 125.5 cm. Italy, Museo di Capodimonte. CWikimedia Commons/Web Gallery of Art.

Gentileschi Artemisia. Susanna and the Elders, 1610. Oil on Canvas, $1.7 \times 1.21 \mathrm{~m}$. Pommersfelden, Germany. CWikimedia Commons/Web Gallery of Art.

Gentileschi, Artemisia to Don Antonio Ruffo, 1649. In Artemisia Gentileschi: The Image of the Female Hero in Italian Baroque Art. Princeton: Princeton University Press, 1988.

Gentileschi, Artemisia to Don Antonio Ruffo, 1649. In Early Modern Europe, 1450 1789, ed. Merry E. Wiesner-Hanks. Milwaukee: Cambridge University Press, 2013. Hibbard, Howard. Caravaggio. New York: Harper \& Row, 1982.

Moir, Alfred. Caravaggio. New York: H.N. Abrams, 1982.

Pollock, Griselda. Differencing the Canon: Feminist Desire and the Writing of Art's Histories. New York: Routledge, 1999.

Zuffi, Stefano. Caravaggio: Masters of Art. Munich, New York: Prestel, 2012. 